УДК 327-043.7(477+470):341.24+341.9

DOI: $10.24144 / 2218-5348.2019 .1-2(19-20) .67-82$

Артьомов Іван,

кандидат історичних наук, доцент, директор НН Інституту євроінтеграційних досліджень ДВНЗ «Ужсгородський національний університет»

\title{
ВИКЛИКИ ЗБРОЙНОЇ АГРЕСІЇ ЯК КАТАЛІЗАТОР ПЕРЕЗАВАНТАЖЕННЯ ЗОВНІШНЬОЇ ПОЛІТИКИ УКРАЇНИ
}

У статті висвітлюються сучасні виклики збройної агресії проти Украӥни, аналізуються базові положення Великого договору з РФ, порівнюється формат двосторонніх відносин між Украйною та Росією $з$ часів отримання незалежності до сьогодення.

За результатами досліджень експертів, політиків, $i$ зокрема академіка Володимира Горбуліна, зроблено висновки та окреслено етапи погіршення зазначених відносин. Наводяться приклади кульмінації $у$ відносинах двох сторін, зокрема аналізуються наслідки для Украӥни та СС «газових воєн» 2006-2009 рр.

Простежуються етапи зростання напруги в контексті перебування Чорноморського флоту РФ у Севастополі, щฺо в кінщевому підсумку привело до анексії Криму.

Автор наводить конкретні приклади застосування Росією комплексного підходу щодо Украӥни з використанням наявних важелів впливу в енергетичній, економічній, суспільно-політичній та гуманітарноінформаційній сферах.

Наголошено, що інтенсивність, характер і иільова спрямованість практичних дій РФ стосовно України мали стратегічну ціль встановлення протекторату над нашою державою $i$ досягнення стратегічної мети, а саме територіального розділу України та включення Півдня $i$ Сходу до складу Російської Федерачії. В подальшому ставилися завдання створення маріонеткового уряду на теренах Центральної України і відмежування від західної частини намої держави як основного «порушника спокою».

На підставі наведених аргументів, щзо базуються на висновках експертів Володимира Горбуліна та Олександра Литвиненка, автор прогнозує подальший розвиток украӥнсько-російських відносин. Разом з ииим автор повністю поділяє висновок експертів про те, щчо в Україні на рубежі 2020-2025 рр. є тільки два шляхи: або стати сильною державою, або зіштовхнутися з реальною небезпекою в перспективі. 
Ключові слова: Україна, Росія, Великий договір, Крим, агресія, зовнішня політика, мінські угоди, нормандський формат, небезпека, перспективи.

The article highlights the contemporary challenges of armed aggression against Ukraine, analyzes the basic provisions of the Great Treaty with Russia, compares the format of bilateral relations between Ukraine and Russia since independence.

According to the research of experts, politicians, and in particular academician Vladimir Horbulin, conclusions were drawn and the stages of deterioration of bilateral relations were outlined. The examples of the culmination of the relations between the two parties are given, in particular, the consequences for Ukraine and the EU of the gas wars 2006-2009 are analyzed.

The stages of tension increase in the context of the Black Sea Fleet presence in Sevastopol are traced, which eventually led to the annexation of Crimea.

The author gives specific examples of Russia's application of a comprehensive approach to Ukraine using the available levers of influence in the energy, economic, social, political and humanitarian fields.

It was emphasized that the intensity, nature and purpose of the practical actions of the Russian Federation towards Ukraine had the strategic purpose of establishing a protectorate over our country and achieving a strategic goal, namely the territorial division of Ukraine and the inclusion of the South and East in the Russian Federation. The task was to set up a puppet government in the territory of Central Ukraine and to distinguish it from the Western part of our state as the main "troublemaker".

Based on the above arguments, based on the findings of experts Vladimir Horbulin and Alexander Litvinenko, the author predicts the further development of Ukrainian-Russian relations on the eve of the meeting of the President of Ukraine in the Normandy format on the situation in the East of Ukraine and in the energy sector. At the same time, the author fully shares the experts' opinion that there are only two ways in Ukraine at the turn of 2020-2025: either to become a strong state or to face a real danger in the future.

Keywords: Ukraine, Russia, the Great Treaty, Crimea, aggression, foreign policy, Minsk agreements, Norman format, danger, prospects.

У лютому 2020 р. минає 5 років з часу анексії Автономної Республіки Крим і м. Севастополь Російською Федерацією. Після Криму розпочалась активна фаза військового протистояння та окупація окремих районів Донецької та Луганської областей.

За даними ООН число жертв в Україні від бойових дій оцінюється такими цифрами [1]: 
УВКПЛ ООН оцінює загальну кількість жертв конфлікта в Україні ( з 14 квітня 2014 р. по 31 жовтня 2019 р.) у 41000 - 44000 осіб: 13 000-13200 загиблих (щонайменше 3345 цивільних осіб, у тому числі 298 загиблих на борту рейсу МН17 «Малазійських авіаліній» 17 липня 2014 р., приблизно 4100 українських військових та приблизно 5650 членів озброєних груп); та 29000 - 31000 поранених (приблизно 7000 - 9000 цивільних осіб, приблизно 9500 - 10500 українських військових і приблизно 12500 - 13500 членів озброєних груп).

Загиблі цивільні особи у загальній кількості загиблих у конфлікті. У загальній кількості смертей, пов'язаних з конфліктом (приблизно 13000 13 200), цивільні особи становлять 25-26 відсотків (щонайменше 3 345).

Таблиия 1

Втрати серед цивільних осіб протягом усього періоду конфлікту, за роками

(осіб)

\begin{tabular}{|l|l|l|l|}
\hline Період & Загиблі & Поранені & Всього \\
\hline 1 січня -31 жовтня 2019 р. & 25 & 130 & 155 \\
\hline 2018 p. & 55 & 224 & 279 \\
\hline 2017 p. & 117 & 487 & 604 \\
\hline 2016 p. & 112 & 476 & 588 \\
\hline 2015 p. & 954 & $>2000$ & $>3000$ \\
\hline 14 квітня - 31 грудня 2014 p. & $2082 *$ & $>4000$ & $>6000$ \\
\hline Всього & 23345 & $>7000$ & $>10000$ \\
\hline
\end{tabular}

* У тому числі 298 загиблих на борту рейсу МН17 «Малазійських авіаліній» 17 липня 2014 p.

Джерело:[1]

Російська збройна агресія кардинально змінила воєнно-політичну обстановку як довкола України, так і на Європейському континенті загалом, а також всередині нашої країни. Анексія Криму, окупація окремих районів Донецької і Луганської областей, утримання під російським контролем Придністров'я сформували «трикутник» реальних загроз Україні. Кожна 3 його «вершин» відіграє свою специфічну роль в антиукраїнській політиці Кремля. Їх сукупність може забезпечити Росії довготривалий негативний вплив на формування та реалізацію внутрішньої і зовнішньої політики України, передусім щодо європейської та євроатлантичної інтеграції. У разі ж реалізації намірів Росії розмістити свою авіабазу на території Білорусі «геометрія» воєнних загроз Україні доповниться північною «вершиною»відмічав Володимир Горбулін [2].

Актуальність статті полягає в узагальненні існуючих в останні роки викликів у відносинах 3 Російською Федерацією та оцінці «млявого» 
реагування на них президентів України Віктора Ющенка та Віктора Януковича.

По-перше, почемо з умов Договору про дружбу, співробітництво i партнерство між Україною та Російською Федерацією від 1 квітня 1999 р.

Після підписання цього документа послідовно було підписано ще 147 міждержавних договорів та угод. Все розпочалося 3 вирішення долі Чорноморського флоту - найважливішої проблеми під час укладання нових відносин між Росією та Україною. Завдяки досягнутим домовленостям було створено міжнародно-правову базу для майбутнього російсько-українських відносин - платформу, на якій вони могли розвиватись на благо народів обох держав, миру, стабільності і співробітництва в Свропі.

Договір про дружбу, співробітництво і партнерство між Україною та Російською Федерацією складається з 41 статті. У ньому підкреслено, що відносини між нашими дружніми рівноправними і суверенними державами трунтуються «на взаємоповазі $i$ довірі, стратегічному партнерстві $i$ співпраці», щзо розглядається як важливий чинник зміцнення глобальної та регіональної стабільності. Обидві держави, сказано у Договорі, «будують відносини одна 3 одною на основі принципів взаємної поваги, суверенної рівності, територіальної цілісності, непорушності кордонів, мирного врегулювання спорів, незастосування сили або загрози силою, включаючи економічні та інші способи тиску, права народів вільно розпоряджатися своєю долею, невтручання у внутрішні справи, додержання прав людини та основних свобод, співробітництва між державами, сумлінного виконання взятих міжнародних зобов'язань, а також інших загальновизнаних норм міжнародного права».

У частині 1 статті 4 [3] зазначено, що держави виходять 3 того, що «добросусідство i співробітництво між ними $є$ важливими факторами зміцнення стабільності і безпеки в Європі і в усьому світі. Вони здійснюють тісне співробітництво з метою зміцнення міжнародного миру і безпеки. Вони вживають необхідних заходів для того, щоб сприяти процесу загального роззброєння, створенню та зміцненню системи колективної безпеки в Свропі, а також посиленню миротворчої ролі ООН і підвищенню ефективності регіональних механізмів безпеки» [4].

Згідно зі ст. 40 [3] Договору, він укладався на десятирічний термін i «його дія буде потім автоматично продовжуватися на наступні десятирічні періоди, якщо жодна з Високих Договірних Сторін не заявить іншій Високій Договірній Стороні про своє бажання припинити його дію шляхом письмового повідомлення не менше ніж за шість місяців до закінчення чергового десятирічного періоду».

Велику увагу було приділено забезпеченню захисту етнічної, культурної, мовної та релігійної самобутності національних меншин, гарантуванню прав осіб, які належать до національних меншин, повністю i 
ефективно здійснювати свої права людини і основні свободи та користуватися ними без будь-якої дискримінації в умовах повної рівності перед законом. Також Сторони зобов'язувались забезпечити сприятливі економічні, фінансові і правові умови для підприємницької та іншої господарської діяльності підприємств і організацій, свободу транзиту осіб, вантажів і транспортних засобів через свої території відповідно до загальновизнаних норм міжнародного права. Країни були зобов'язані приділити особливу увагу розвитку співробітництва в забезпеченні функціонування національних паливно-енергетичних комплексів, транспортних систем і систем зв'язку та інформатики, сприяючи збереженню, раціональному використанню і розвитку комплексів та єдиних систем, що склалися у цих галузях.

На сьогоднішній день існує багато суперечок навколо статті 6 Договору, де йдеться про те, що Сторони зобов'язуються утримуватися «від участі або підтримки будь-яких дій, спрямованих проти другої Високої Договірної Сторони», «не укладати з третіми країнами будь-яких договорів, спрямованих проти другої Сторони», а також не допускати, «щоб іiї територія була використана на шкоду безпеці другої Сторони».

18 вересня 2008 р. президент РФ Д. Медведєв, приймаючи в Олександрійському залі Кремля вірчі грамоти у посла України в Росії К. Грищенка, заявив: «Народи Росії і України нерозривно зв'язують посправжньому братерські відносини і особливі відчуття пошани і взаємної довіри» [5]. Отже, незважаючи на взаємні претензії, Україна та Росія все ж таки продовжили дію Договору.

Україна була налаштована будувати відносини з Росією на принципах добросусідства, рівноправ'я, 3 повагою до незалежності кожного 3 народів, права суверенної нації формувати свою політику з ключових внутрішніх і зовнішніх питань. 1 жовтня 2008 р. було зроблено правову пролонгацію функціонування цього Договору ще на 10 років, таким чином, i Україна, i Росія 3 розумінням підійшли до того, наскільки важливі основоположні принципи цієї Угоди для розвитку у перспективі наших двосторонніх відносин [6].

Подальші дії РФ щодо України засвідчили системне односторонне трактування умов Великого договору на основі не рівноправного партнера, а «меншого» брата. Наведемо підтвердження цього висновку.

По-перше, починаючи 32006 р. Росія для реалізації своїх цілей застосовує комплексний підхід 3 використанням впливу на Україну в енергетичній, економічній і гуманітарно-інформаційній сферах. Яскравим прикладом такого тиску стали відомі події «газових війн» 2005-2006 рр. та 2008-2009 pp. [7]. 
По-друге, відбувається послідовна компрометація політики України в цих сферах від двосторонніх відносин до впливу на геополітичноглобальному рівнях [8].

По-третє, основним полігоном для відпрацювання політики Кремля щодо України $є$ Крим з метою отримання вирішального впливу на політику Києва, особливо в контексті загроз національній безпеці [9].

Підписання Угоди між Україною та Російською Федерацією з питань перебування Чорноморського флоту Російської Федерації на території України (так звані «Харківські угоди») засвідчило започаткування нового етапу тиску на Україну, особливо в контексті базування у Севастополі Чорноморського флоту [10].

Широкий спектр прихованих загроз для України від РФ можна продовжувати, але найбільш синтезовано вони згруповані в статті для «Дзеркала тижня» екссекретаря Ради національної безпеки України академіка Володимира Горбуліна і доктора політичних наук Олександра Литвиненка [11]. На їх думку, російський наступ на Київ розпочнеться упродовж найближчих п’яти років (прим. - стаття вийшла друком у 2009 р.).

На думку експертів, нові плани щодо України були озвучені у серпневій заяві російського президента Дмитра Медведєва і у близькому за змістом розгорнутому виступі депутата Державної думи РФ Костянтина Затуліна у травні 2009 року. «Йдеться фактично про ультиматум, що збереження територіальної цілісності України зумовлюється ії переходом до «особливих відносин» з РФ, а фактично - до російського протекторату над слабкою Україною», - зазначають Горбулін і Литвиненко.

При тому, на думку фахівців, у Кремля поки відсутній детальний план досягнення цієї мети, і Росія готова діяти ситуативно. «Мова не про розроблений план дій, а саме про стратегічні цілі та завдання, напрями і пріоритети. Поточні конкретні дії Москви визначатимуться перебігом ситуації і насамперед реакцією України», - наголошують експерти.

В. Горбулін і О. Литвиненко не виключали, що протекторат над Україною не $\epsilon$ кінцевою зовнішньополітичною ціллю Російської Федерації. «Не виключено, що встановлення протекторату може розглядатися лише як перехідний етап для подальшого територіального розділу України, ймовірно на три частини, за моделлю, оприлюдненою, швидше за все, російською розвідкою в італійському геополітичному журналі Limes», - припускали фахівці.

У зазначеній моделі, за словами Горбуліна і Литвиненка, йдеться про пряме включення Півдня і Сходу України до складу РФ, створення маріонеткового уряду на теренах Центральної України та відмежування від Західної як основного «порушника спокою». 
«Агресивна політика Кремля щодо України викликана не діями Києва, а потребами Росії, як їх усвідомлює нинішнє керівництво держави. Тобто навіть кардинальна зміна Україною політичного курсу не призведе до істотної корекції російської політики та не відмінить уже визначених цілей», - відзначали експерти [12].

«Підпорядкування України, або принаймні іiї південно-східної частини, Кремлю має істотно поліпшити ситуацію в РФ. Зокрема, пом'якшити демографічні проблеми, забезпечити надійний транзит енергоносіїв до Європи, значно збільшити економічний потенціал, насамперед у машинобудуванні, сільському господарстві, унеможливити отримання США територіального плацдарму у безпосередній близькості від Москви», - констатують експерти.

«У Кремлі усвідомлюють, що історичне «вікно можливостей» щодо України для Москви доволі коротке i може зачинитися вже десь після 2015 року, після становлення нового покоління українських еліт, відзначають експерти. - Отже, «наступ на Київ» розгорнеться вже найближчим часом і буде рішучим та безпощадним».

Як засвідчує сьогодення, передбачення В. Горбуліна щодо подальшого розвитку конфліктогенних чинників в українсько-російських відносинах стали реальністю.

3 огляду на обсяг статті, наведемо коротку хронологію розвитку подій, яка майже на сто відсотків підтвердила передбачення політичних аналітиків щодо розвитку російсько-українських відносин.

\section{Хронологія початку російсько-української війни}

18 лютого 2014 p. - спроба силового розгону Майдану.

20 лютого - наступ протестувальників, масове застосування вогнепальної зброї проти них.

21 лютого о 16:52 - Верховна Рада України прийняла Закон України "Про відновлення дії окремих положень Конституції України" (положень 2004 року).

22 лютого - в умовах самоусунення Президента України і Верховного Головнокомандувача Збройних Сил Віктора Януковича від виконання конституційних повноважень, відповідно до Конституції України на Голову Верховної Ради України було покладено виконання обов'язків Президента України. У стислі строки призначили нове керівництво органів сектору безпеки й оборони, сформували новий уряд України, відновили діяльність органів виконавчої влади в Києві та регіонах.

\section{Події у Криму. Окупація}

20 лютого 2014 року - Дата початку збройної агресії, зафіксована на відомчій медалі Міноборони Росії “За повернення Криму”.

23 лютого - Найбільший мітинг проросійських сил у Севастополі. 3 трибуни вперше пролунали заклики не визнавати нову українську владу. 
Бутафорне “обрання" на площі “народного мера" Севастополя - російського бізнесмена Олексія Чалого. Цього ж дня відбувся мітинг у Москві із закликами до поділу України на три частини, направлення російських “добровольців” для проголошення Малоросії зі столицею в Харкові. В російській пресі розгорнулася істерія про "незаконну київську хунту" й “порятунок російськомовного населення України від фашистів-бандерівців".

24 лютого - кораблі ВМФ РФ, які здійснювали охорону морської акваторії в районі проведення Сочинської олімпіади, прийняли на борт в Новоросійську “зелених чоловічків” (російських військовослужбовців без розпізнавальних знаків ЗС РФ, яких використовували для захоплення адміністративних будівель та блокування українських військових частин на території АРК та Севастополя) з бойовою технікою та вийшли курсом на Севастополь.

26 лютого - мітинги під Верховною Радою АРК: один проросійських організацій 3 вимогою автономії у складі Росії (близько 2 тисяч учасників), інший - місцевих українських патріотів і кримських татар за територіальну цілісність України (зібрав 5-10 тисяч учасників). Проросійські сили очікували, що Верховна Рада АРК ухвалить рішення про заклик щодо допомоги Росії. Щоб не допустити цього, зібрався проукраїнський мітинг. Між учасниками виникли сутички, постраждало 30 осіб. Кримський парламент під тиском відмовився від гучних заяв.

27 лютого - російські військові без розпізнавальних знаків заблокували парламент та уряд АРК у Сімферополі.

28 лютого - Верховна Рада Автономної Республіки Крим під наглядом російських військовослужбовців із 31-ї десантно-штурмової бригади ЗС РФ проголосувала за проведення референдуму про статус Криму, призначила представника партії "Русское единство" Сергія Аксьонова головою уряду Криму.

16 березня - відбувся псевдореферендум про статус Криму. Зрежисований Росією захід бойкотували кримські татари та проукраїнськи налаштоване населення. За оголошеними організаторами результатами, 96,77\% учасників проголосували “за возз'єднання Криму з Росією на правах суб'єкта Російської Федерації”. Конституційний Суд України визнав неконституційною постанову Верховної Ради АР Крим, згідно 3 якою провели референдум.

18 березня в Москві президент Росії Володимир Путін, “голова Ради міністрів Республіки Крим" Сергій Аксьонов, “спікер Верховної Ради Республіки Крим" Володимир Константінов і “Голова Координаційної ради 3 організації управління по забезпеченню життєдіяльності Севастополя" Олексій Чалий підписали Договір про прийняття Республіки Крим до складу Pociï. 
21 березня - Путін підписав указ про ратифікацію договору про прийняття Криму до складу РФ.

25 березня - захоплено останню військову частину, що тримала український прапор в Криму - тральщик ВМС “Черкаси". Автономна Республіка Крим і Севастополь окуповані ЗС РФ.

26 березня - українські військові взяли під контроль радіонавігаційну станцію "Марс-75" у Генічеську (Херсонська область), яку Чорноморський флот РФ незаконно утримував з 1998 року і, всупереч рішенням судів, не допускав на іï територію співробітників державної виконавчої служби та правоохоронців України [13].

Другий, затяжний етап військового протистояння розпочався після втрати Україною окремих районів Донецької і Луганської областей i продовжується донині. Як будуть в подальшому розвиватися події на Сході України, покаже час.

У той же час вимогою сьогодення $є$ перезавантаження не лише зовнішньої, а й внутрішньої політики держави. Вважаємо дуже актуальною, у контексті вищенаведеного, потребу врахувати пропозиції Володимира Горбуліна [11]:

- $\quad$ негайно відновити політичну стабільність на основі елітного і суспільного консенсусу щодо європейського шляху розвитку України. Політична конкуренція не має набувати руйнівних форм i загрожувати безпеці держави. Україна має нарешті вилікувати небезпечний комплекс віктимної поведінки;

- на такій основі необхідно відновити ефективність державної влади. Отже, слід, по-перше, подолати багатополюсність виконавчої влади;

- по-друге, слід подолати політичний принцип призначення на посади у виконавчій владі. Основним критерієм для призначення державних службовців має бути їх професіоналізм, репутація та відданість інтересам держави, а не належність до певної політичної сили. Нарешті мають бути розділені адміністративні та політичні посади;

- по-трете, необхідно значно знизити рівень корумпованості державного апарату. Для цього слід здійснити дерегуляцію економіки, ухвалити та забезпечити застосування вже розробленого антикорупційного законодавства, забезпечити антикорупційну експертизу проектів нормативно-правових актів, а також слід посилити поліційну складову боротьби з корупцією, зокрема провівши кілька показових судових процесів;

- по-четверте, слід реформувати Збройні сили виходячи з умов невступу України протягом найближчих п'яти років до НАТО, а також із завдання неприйнятної шкоди можливому агресору, насамперед в асиметричний спосіб. При цьому слід виходити 3 неможливості різкого збільшення фінансування оборонного бюджету. Отже, слід забезпечити кардинальне скорочення 3С без втрати потенціалу для розгортання на їх 
основі повноцінної армії, сконцентрувавши наявні матеріально-фінансові, кадрові та інтелектуальні ресурси на двох-трьох основних напрямах. Практику ж проведення парадів до Дня незалежності, важливих для патріотичного виховання, слід доповнити, а може, й на певний період замінити проведенням військових навчань у регіонах України;

Довідково. Якщуо на початок агресї чисельність Збройних сил становила 150 тис. осіб, то сьогодні службу несуть 255 тис. військовослужбовців, з яких лише 20 тис. осіб строкової служби. Підготовка сучасного військового - це великозатратні видатки. Для прикладу: Великобританія - 250 тис. фунтів; Німеччина - 220 тис. свро; Польщза приблизно 100 тис. євро; Росія - 83 тис. євро; Албанія - 20-25 тис. євро; Україна - y 2017p. 8 тис. євро, а у 2018 p. - 12 тис. євро.

Бюджет Міністерства оборони також змінився за чей період: 2014 р. бюджет Міноборони становив 27 млрд. грн.; у 2015 р. - 42 млрд. грн.; у 2016 р. - 57 млрд. грн.; у 2017 р. - 64 млрд. грн.; 2018 р. - 86 млрд. грн. [14]. Бюджетом України на 2020 р. передбачено вже 245 млрд. грн. [15].

- по-п'яте, необхідно створити ефективну розвідку і контррозвідку, сконцентровані на вирішенні кількох чітко визначених завдань. При цьому варто усвідомлювати, що основна проблема полягає не в обсягах фінансування, а в нинішньому стані відповідних структур;

- по-шосте, варто активізувати інформаційну кампанію, спрямовану як на населення України, так і на Росію, інші країни СНД i Європи. Метою цієї кампанії має стати роз'яснення української політики, іiі цілей, засобів і перебігу, формування позитивного іміджу держави, пропаганда культурних, економічних та інших досягнень України. Ключовим завданням повинен бути розвиток англомовних інформаційних ресурсів про Україну, принаймні переклад чинного українського законодавства та створення сучасних англомовних мережевих сторінок державних органів.

Визначаючи державну політику, необхідно виходити 3 того, що російськомовне населення України - це важливий чинник суспільного розвитку, що існуватиме принаймні ще два-три покоління. Отже, необхідні термінові розробка і реалізація цілеспрямованої державної програми щодо російськомовних громадян України, яка передбачала б проведення російськомовної проукраїнської пропагандистської кампанії, підтримку у Криму, на Півдні і Сході України російськомовних ЗМІ відповідного спрямування тощо. Необхідно сприяти створенню і розвитку демократично, проєвропейсько орієнтованих громадських i політичних організацій, що працюватимуть у російськомовному середовищі.

На закінчення статті відзначимо активізацію діяльності законодавчих гілок влади в Україні, які останніми роками прийняли надважливі правові акти, реалізація яких дозволить мінімізувати існуючі виклики для України. Назвемо лише окремі з них, а саме: 
- Закон України «Про забезпечення прав і свобод громадян та правовий режим на тимчасово окупованій території України» [16];

- Закон України «Про особливості державної політики із забезпечення державного суверенітету України на тимчасово окупованих територіях у Донецькій та Луганській областях» [17];

- Закон України «Про національну безпеку України» [18];

- Указом Президента України затверджено рішення РНБО «Про Стратегію національної безпеки України» [19], основними цілями якої є: мінімізація загроз державному суверенітету та створення умов для відновлення територіальної цілісності України у межах міжнародно визнаного державного кордону України тощо;

- Указом Президента України затверджено рішення РНБО «Про нову редакцію воєнної доктрини України» [20]. Воєнна доктрина України є концептуальним документом, що аналізує сутність i характер сучасних воєнних конфліктів, визначає принципи і шляхи запобігання їх виникненню, підготовку держави до загрози воєнного конфлікту, застосування воєнної сили для захисту державного суверенітету, територіальної цілісності, інших життєво важливих національних інтересів.

Важливою платформою вирішення проблем Донбасу стали підсумки саміту Нормандської четвірки, який відбувся 9 грудня ц. р. у Парижі. Свідченням цього $є$ положення Комюніке саміту, в якому зазначено таке:

\section{1. Невідкладні заходи зі стабілізації ситуації в зоні конфлікту:}

Сторони віддані повній та всеохоплюючій імплементації режиму припинення вогню, підкріпленого реалізацією всіх необхідних заходів 3 підтримки режиму припинення вогню до кінця 2019 року.

Вони підтримають розробку та імплементацію оновленого плану 3 розмінування на основі рішення Тристоронньої контактної групи про протимінну діяльність від 3 березня 2016 року.

Вони підтримають домовленість у рамках Тристоронньої контактної групи щодо трьох додаткових ділянок розведення з метою розведення сил і засобів до кінця березня 2020 року.

Вони заохочують Тристоронню контактну групу сприяти звільненню та обміну утримуваних осіб, пов'язаних 3 конфліктом, до кінця року на основі принципу "всіх на всіх", починаючи з "усіх встановлених на всіх встановлених", при розумінні, що міжнародним організаціям, включно 3 Міжнародним комітетом Червоного Хреста (МКЧХ), буде надано повний i безумовний допуск до всіх утримуваних осіб. Вони підтримають досягнення протягом 30 днів домовленості в рамках Тристоронньої контактної групи про нові пункти пропуску через лінію розмежування, виходячи передусім 3 гуманітарних критеріїв.

Вони нагадують, що Спеціальна моніторингова місія (СMM) Організації безпеки і співробітництва в Європі має бути спроможною 
використовувати усі можливості мандата (від 21 березня 2014 року) і мати безпечний i надійний доступ на всій території України з метою повного виконання свого мандата.

2. Заходи 3 імплементації політичних положень Мінських угод: Сторони висловлюють зацікавленість у досягненні домовленостей у рамках нормандського формату (H4) i Тристоронньої контактної групи щодо всіх правових аспектів особливого порядку місцевого самоврядування (особливого статусу) окремих районів Донецької та Луганської областей - як зазначено в Комплексі заходів щодо виконання Мінських угод від 2015 року для забезпечення його дії на постійній основі.

Вони вважають за необхідне інкорпорувати "формулу Штайнмаєра" в українське законодавство згідно 3 версією, узгодженою $\mathrm{H4}$ та Тристоронньою контактною групою.

\section{3. Подальші кроки:}

Вони просять своїх міністрів закордонних справ та політичних радників забезпечити виконання досягнутих домовленостей, i вони погодилися провести ще одну зустріч у цьому форматі впродовж чотирьох місяців стосовно політичних та безпекових умов, серед іншого - для організації місцевих виборів [21].

Реалізація положень саміту вкрай важлива. За словами В.П. Горбуліна, в України на рубежі 2020-2025 рр. є тільки два шляхи: або стати сильною державою, або зіштовхнутися 3 реальною небезпекою [2]. Будемо сподіватися, що Україна вибере перший шлях.

\section{Список використаних джерел}

1. ООН порахувала жертви бойових дій на Донбасі серед цивільних i комбатантів. URL: https:/www.radiosvoboda.org/a/oon-zvit-ghertvydonbas/30272212.html

2. Донбас i Крим: ціна повернення: монографія / за заг. ред. В.П. Горбуліна, О. С. Власюка, Е. М. Лібанової, О. М. Ляшенко. К. : НІСД, 2015. - $474 \mathrm{c}$.

3. Договір про дружбу, співробітництво i партнерство між Російською Федерацією і Україною від 31 травня 1997 р. / Верховна Рада України [сайт]. URL: http://zakon4.rada.gov.ua/laws/show/643_006.

4. Закон України «Про міжнародні договори України» 29 червня від 2004 року // Відомості Верховної Ради України. 1992. № 10. Ст. 137.

5. Україна хоче отримати від "Газпрому" гарантії завантаження ГТС газом. URL: // http://www.newsru. ua/finance/21aug2010/gaz.html.

6. Медведєв вважає, що ніщо не завадить братерським відносинам України та Pociï. URL: http://kyiv.comments. ua/country/2008 /09/18/143432.html. 
7. Ісевич Є. Україна-Росія: газові війни, а що далі? // Геополітика України: історія і сучасність: збірник наукових праць. Вип. 2 (15). /ред. кол.: І.В.Артьомов (голова) та ін. Ужгород: ДВНЗ «УжНУ», 2015. 244 с. С.69-72.

8. Тодоров І., Тодорова Н. Українські міжрегіональні відмінності в контексті російської агресії проти України в 2014-2015 pp. // Геополітика України: історія і сучасність: збірник наукових праць. Вип. 1 (14). / ред. кол.: І.В. Артьомов (голова) та ін. Ужгород: ДВНЗ «УжНУ», 2015. 236 с. С. 29-42.

9. Власюк О. В., Кононенко С. В. Актуальні аспекти вдосконалення моделі національної безпеки України // Стратегічна панорама: щоквартальний науково-практичний журнал / за заг. ред. Горбуліна В.П. Київ, 2017, Вип. 1. С.17-23.

10. Угода між Україною та Російською Федерацією 3 питань перебування Чорноморського флоту Російської Федерації на території України (укр/poc). URL: https://zakon.rada.gov.ua/laws/show/en/643_359

11. Експерти: Стратегічною ціллю РФ є встановлення протекторату над Україною. URL: https://dt.ua/POLITICS/eksperti_ strategichnoyu tsillyu_rf_e_vstanovlennya_protektoratu_nad_ukrayinoyu.html

12. Експерти: Агресія проти України зумовлена внутрішньою ситуацією в РФ. URL: https://dt.ua/POLITICS/eksperti_agresiya_proti_ukrayini_ zumovlena_vnutrishnoyu_situatsieyu_v_rf.html

13. До 5-річчя від початку збройної агресії Російської Федерації проти України. URL: https://uinp.gov.ua/informaciyni-materialy/viyskovym/do5-richchya-vid-pochatku-zbroynoyi-agresiyi-rosiyskoyi-federaciyi-proty-ukrayiny

14. Артьомов І.В. Правові та зовнішньополітичні засади національної безпеки України: актуальні аспекти // Геополітика України: історія і сучасність: збірник наукових праць. Вип. 1 (20). / ред.кол.: І.В. Артьомов (гол.ред.) та ін. Ужгород: ДВНЗ «УжНУ», 2018. 292 с. С.55-56.

15. Рада проголосувала за Держбюджет на 2020 рік: основні цифри. URL: https://24tv.ua/opublikuvali_tekst_proyektu_byudzhetu_na_2020_ rik_ osnovni_tsifri_n1206081

16. Закон України «Про забезпечення прав і свобод громадян та правовий режим на тимчасово окупованій території України». URL: https://zakon.rada.gov.ua/laws/show/1207-18

17. Закон України «Про особливості державної політики із забезпечення державного суверенітету України на тимчасово окупованих територіях у Донецькій та Луганській областях». URL: https://zakon.rada.gov.ua/laws/show/2268-19/paran2

18. Закон України «Про національну безпеку України». URL:https://zakon.rada.gov.ua/laws/show/2469-19

19. Про рішення Ради національної безпеки і оборони України від 6 травня 2015 року "Про Стратегію національної безпеки України". URL: https://zakon.rada.gov.ua/laws/show/287/2015 
20. Про нову редакцію Воєнної доктрини України. URL: https://zakon.rada.gov.ua/laws/show/en/n0016525-15

21. Декларація саміту "нормандської четвірки": повний текст. URL: https://www.eurointegration.com.ua/articles/2019/12/10/7104049/

\section{REFERENCES}

1. OON porakhuvala zhertvy boyovykh diy na Donbasi sered tsyvil'nykh i kombatantiv [The UN has counted civilian and combatant casualties in the Donbas]. radiosvoboda.org. Retrieved from https://www.radiosvoboda.org/ a/oonzvit-ghertvy-donbas/30272212.html [in Ukrainian].

2. Horbulin, V. P., Vlasyuk, O. S., Libanova, E. M., Lyashenko, O. M. (2015). Donbas i Krym: tsina povernennya [Donbass and Crimea: return price]. Kyiv: NISD [in Ukrainian].

3. Dohovir pro druzhbu, spivrobitnytstvo i partnerstvo mizh Rosiys'koyu Federatsiyeyu i Ukrayinoyu vid 31 travnya 1997 r. [Friendship, Cooperation and Partnership Agreement between the Russian Federation and Ukraine of May 31, 1997]. zakon4.rada.gov.ua. Retrieved from http://zakon4.rada.gov.ua/laws/ show/643_006 [in Ukrainian].

4. Zakon Ukrayiny «Pro mizhnarodni dohovory Ukrayiny» 29 chervnya vid 2004 roku (1992) [Law of Ukraine "On International Treaties of Ukraine"]. No. 10. - St. 137 [in Ukrainian].

5. Ukrayina khoche otrymaty vid "Hazpromu" harantiyi zavantazhennya $\mathrm{HT} \cdot \mathrm{S}$ hazom [Ukraine wants to get gas supply guarantee from Gazprom]. newsru.ua. Retrieved from http://www.newsru. ua/finance/21aug2010 /gaz.html [in Ukrainian].

6. Medvedyev vvazhaye, shcho nishcho ne zavadyt' braters'kym vidnosynam Ukrayiny ta Rosiyi [Medvedev believes that nothing will hurt the brotherly relations of Ukraine and Russia]. kyiv.comments.ua. Retrieved from http://kyiv.comments.ua/country/2008/09/18/143432.html [in Ukrainian].

7. Isevych, YE. (2015). Ukrayina-Rosiya: hazovi viyny, a shcho dali? [Ukraine-Russia: Gas Wars, What's Next]. Heopolityka Ukrayiny: istoriya $i$ suchasnist - Geopolitics of Ukraine: History and Modern Times, 2 (15), 69-72. Uzhhorod: DVNZ «UzhNU» [in Ukrainian].

8. Todorov I., \& Todorova, N. (2015). Ukrayins'ki mizhrehional'ni vidminnosti v konteksti rosiys'koyi ahresiyi proty Ukrayiny v 2014-2015 rr. [Ukrainian Interregional Differences in the Context of Russian Aggression against Ukraine in 2014-2015]. Heopolityka Ukrayiny: istoriya i suchasnist - Geopolitics of Ukraine: History and Modern Times, 1 (14), 29-42. Uzhhorod: DVNZ «UzhNU» [in Ukrainian].

9. Vlasyuk, O. V., \& Kononenko, S. V. (2017). Aktual'ni aspekty vdoskonalennya modeli natsional'noyi bezpeky Ukrayiny [Actual Aspects of 
Improving the Model of National Security of Ukraine]. Stratehichna panorama Strategic Panorama, 1, 17-23. Kyyiv [in Ukrainian].

10. Uhoda mizh Ukrayinoyu ta Rosiys'koyu Federatsiyeyu z pytan' perebuvannya Chornomors'koho flotu Rosiys'koyi Federatsiyi na terytoriyi Ukrayiny ( $\mathrm{ukr} / \mathrm{ros}$ ) [Agreement between Ukraine and the Russian Federation on the stay of the Black Sea Fleet of the Russian Federation in the territory of Ukraine]. zakon.rada.gov.ua. Retrieved from https://zakon.rada.gov.ua/laws/ show/en/643_359 [in Ukrainian].

11. Eksperty: Stratehichnoyu tsillyu RF ye vstanovlennya protektoratu nad Ukrayinoyu [Experts: The Russian strategic goal is to establish a protectorate over Ukraine]. dt.ua. Retrieved from https:/dt.ua/POLITICS/ eksperti_strategichnoyu_tsillyu_rf_e_vstanovlennya_protektoratu_nad_ukrayinoyu .html [in Ukrainian].

12. Eksperty: Ahresiya proty Ukrayiny zumovlena vnutrishn'oyu sytuatsiyeyu v RF [Experts: Aggression against Ukraine is caused by internal situation in Russia]. dt.ua. Retrieved from https:/dt.ua/POLITICS/ eksperti_agresiya_proti_ukrayini_zumovlena_vnutrishnoyu_situatsieyu_v_rf.html [in Ukrainian].

13. Do 5-richchya vid pochatku zbroynoyi ahresiyi Rosiys'koyi Federatsiyi proty Ukrayiny [To the 5th anniversary of the beginning of the armed aggression of the Russian Federation against Ukraine]. uinp.gov.ua. Retrieved from https://uinp.gov.ua/informaciyni-materialy/viyskovym/do-5-richchya-vidpochatku-zbroynoyi-agresiyi-rosiyskoyi-federaciyi-proty-ukrayiny [in Ukrainian].

14. Art'omov, I.V. (2018). Pravovi ta zovnishn'opolitychni zasady natsional'noyi bezpeky Ukrayiny: aktual'ni aspekty [Legal and foreign policy principles of national security of Ukraine: current aspects]. Heopolityka Ukrayiny: istoriya $i$ suchasnist - Geopolitics of Ukraine: History and Modern Times, 1 (20), 55-56. Uzhhorod: DVNZ «UzhNU» [in Ukrainian].

15. Rada proholosuvala za Derzhbyudzhet na 2020 rik: osnovni tsyfry. [The Council voted for the State Budget for 2020: key figures.]. 24tv.ua. Retrieved from

https://24tv.ua/opublikuvali_tekst_proyektu_byudzhetu_na_2020_rik_osnovni_tsif ri_n1206081 [in Ukrainian].

16. Zakon Ukrayiny «Pro zabezpechennya prav i svobod hromadyan ta pravovyy rezhym na tymchasovo okupovaniy terytoriyi Ukrayiny» [The Law of Ukraine "On Ensuring the Rights and Freedoms of Citizens and the Legal Regime in the Occupied Territory of Ukraine"]. zakon.rada.gov.ua. Retrieved from https://zakon.rada.gov.ua/laws/show/1207-18 [in Ukrainian].

17. Zakon Ukrayiny «Pro osoblyvosti derzhavnoyi polityky iz zabezpechennya derzhavnoho suverenitetu Ukrayiny na tymchasovo okupovanykh terytoriyakh u Donets'kiy ta Luhans'kiy oblastyakh» [The Law of Ukraine "On Features of State Policy for Ensuring State Sovereignty of Ukraine in Temporarily 
Occupied Territories in Donetsk and Luhansk Regions".]. zakon.rada.gov.ua. Retrieved from https://zakon.rada.gov.ua/laws /show/2268-19/paran2 [in Ukrainian].

18. Zakon Ukrayiny «Pro natsional'nu bezpeku Ukrayiny» [Law of Ukraine "On National Security of Ukraine"]. zakon.rada.gov.ua. Retrieved from https://zakon.rada.gov.ua/laws/show/2469-19 [in Ukrainian].

19. Pro rishennya Rady natsional'noyi bezpeky i oborony Ukrayiny vid 6 travnya 2015 roku "Pro Stratehiyu natsional'noyi bezpeky Ukrayiny" [On the decision of the National Security and Defense Council of Ukraine of May 6, 2015 "On the National Security Strategy of Ukraine"]. zakon.rada.gov.ua. Retrieved from https://zakon.rada.gov.ua/laws/show/287/2015 [in Ukrainian].

20. Pro novu redaktsiyu Voyennoyi doktryny Ukrayiny [On the new version of the Military Doctrine of Ukraine]. zakon.rada.gov.ua. Retrieved from https://zakon.rada.gov.ua/laws/show/en/n0016525-15 [in Ukrainian].

21. Deklaratsiya samitu "normands'koyi chetvirky": povnyy tekst [Normandy Four Summit Declaration: Full Text]. eurointegration.com.ua. Retrieved from https://www.eurointegration.com.ua/articles/2019/12/10/7104049/ [in Ukrainian]. 